\title{
Environmental attitudes, community development, and local politics in Ireland
}

\author{
Paul Collinson
}

Anyone who has ever visited Ireland will be immediately struck by the natural beauty of the country. From the rugged uplands of the west, the golden beaches of Cork and Kerry, the rolling drumlins of the midlands to the sea cliffs of the north, Ireland is undoubtedly blessed with one of the richest and most diverse environmental endowments in Europe. Attracted by tourist brochures and advertisements which play heavily on images of Ireland as a rural paradise, tourists flock to the country each summer in their hundreds of thousands, hoping to discover the pristine, unspoiled countryside promised by the government's marketing campaigns.

However, the gap between image and reality in Ireland is growing ever wider. Much has been written about the deleterious effects the unprecedented economic growth of the 1990s and 2000s had on Ireland's environment (e.g. Meldon 1992; Dillon 1996; Deegan and Dineen 1997; Wickham and Lohan 2000; McDonagh 2007), and those who visit the country today to actively seek out what is promised in the tourist brochures may well return home disappointed - even though the famed 'Celtic Tiger' is, at the time of writing, dormant, and possibly extinct. The political rise of the Irish Green Party, which was in government since 2006 in coalition with Ireland's most dominant political party in the post-independence era, Fianna Fáil, and the party's subsequent spectacular fall (losing all its members of parliament in the 2011 election $)^{1}$ exemplifies the ambiguous and complex attitude which the Irish population have towards their environment.

The economic crisis of recent years has thrown into stark relief the impact on the environment of one of the most visible spin-offs of Ireland's erstwhile prosperity: the housing boom. In many areas of the country, a new phenomenon of the 'ghost' housing estate has emerged, characterised by row upon row of unsold new homes in which no one lives, often located in areas of the country where no one apparently wants to live either. One estimate calculated that Ireland's excess housing stock amounted to 136,000 homes in 2009 (DKM 2009), a quite staggering figure in a country with a total population of only around 4.5 million. Some have proposed that these estates should be bought by the government from developers and bulldozed back into agricultural land (Irish Examiner 2010).

In this chapter, I wish to explore some of these themes through an examination of development activity in County Donegal, Ireland's most northerly county. It is 
based largely on anthropological fieldwork conducted in the late 1990s (Collinson 1999), along with data collected during visits made to Ireland since then. My contention is that the historical neglect of environmental concerns in the overall development agenda in Ireland has above all a social basis, in the sense that it is manifested in the divisions which exist between community and environmental development groups - as well as with local councils - at local levels.

I begin with a survey of Irish attitudes to the environment, together with a consideration of how community and environmental development approaches are distinguished in the country. The research material that follows has been chosen to draw out some of the contrasts between those involved in each type of group by focusing on the social nexus in which each operates, and by comparing the different attitudes each holds towards the environment and environmental development in general. ${ }^{2}$

\section{Irish attitudes to the environment}

Attitude surveys have consistently demonstrated that the Irish population have, historically, a somewhat ambivalent approach to the environment. This is reflected in the number of people involved in environmental development groups. Motherway, Kelly, Faughnan, and Tovey's survey of environmental attitudes and behaviour among the population conducted in the early 2000s found that formal membership of environmental groups was low, at 3 per cent of the sample, with most people's engagement with environmental concerns largely confined to recycling (which had increased significantly over the previous ten years) and the periodic signing of petitions (Motherway et al. 2003: 46). The survey also found that concerns over the environment (and a willingness to pay for its protection) were strongly related to the wealth of a household (Motherway et al. 2003: 28). A similar survey by Kelly (2004) found the rate of membership of environmental groups in Ireland is among the lowest of European countries. Also, the Irish government itself was late to recognise the importance of environmental sustainability, in part through an incorporation of EU regulations and programmes focused on the environment (Coyle 1994; Tovey, Share, and Corcoran 2007).

These observations provide a partial explanation for the discernible dichotomy between 'community' and 'environmental' development in Ireland. Although the country has a strong tradition of community activism against the activities of potential polluters, predominantly multinationals, which has sometimes resulted in the relocation or closure of factories (Coyle 1994; Yearley 1995; Leonard 2007), until recently this has largely remained within the confines of 'NIMBYism' 3 and cannot be said to have emerged from a genuinely 'green' political movement. In Tovey's view:

Much of the initial environmental protest in Ireland was exceptional in that it was directed at industrial pollution or associated mining and dumping; it was targeted to a large degree at foreign firms; and it involved local, usually community-based 
organisations whose values had more to do with family and community than those of the international conservation movement. (Tovey 2007: 20-1)

The development debate in Ireland has historically been somewhat one-dimensional, economic considerations usually taking precedence over everything else (Tovey 2007). And while the concept of sustainable development is now established in the mainstream national development discourse, some argue that Ireland lags behind much of continental Europe in the way development itself is conceived (e.g. Kelly 2004; Barry and Doran 2009; Flynn 2009). There is little reference, for example, to the relationship between development and political change (Sklair 2009), which many would argue is a precondition for genuine sustainability (Varley 2009). The primacy of economics is unsurprising, given Ireland's history of 'underdevelopment' and historic (and re-emerging) problems associated with emigration, long-term structural unemployment and social exclusion, but its legacy has been to marginalise environmental concerns.

\section{Community development in Ireland}

Ireland has a very strong tradition of local community development. It is rooted in ancient rural practises such as cooring, the sharing of agricultural labour, and meitheal, meaning community solidarity and mutual support. Community development emerged historically from the failure of the State to provide adequately for its citizens, and has therefore been seen as a local response to the inadequacy of centralised development planning (Curtin 1997). However - and at the risk of overgeneralisation - much of it has virtually always been, and continues to be, couched around mainstream development models, prioritising the central tenets of the State's development goals and often acting in partnership with it (Tovey 2007).

Community development gained impetus during the 1940s and 1950s when a national rural development movement was established called Muntir na Tir, the aims of which were to combat the shocking poverty of the population and stem the tide of mass out-migration from the country. Founded by a Tipperary-based priest, Fr John Hayes, Muntir na Tir's local organisation was based upon Catholic parishes, and social Catholicism represented its primary development model from the outset. While Muntir na Tir did attempt to develop self-reliance and local autonomy among the communities it worked in, it was always (and continues to be) dependent on state funding, articulated through a partnership approach to engagement with state bodies: a relationship that has since been replicated throughout much of the community development sector (Varley 2009).

This legacy, along with the long association of community development with rurality and agriculture, means that the environment has been seen largely as a resource to be exploited, and environmental concerns have never featured very strongly in the community development agenda traditionally; indeed, one could argue that it 
has been almost anti-environmentalist in its outlook (e.g. Skillington 1997; 1998; Peillon 2002). The main focus for most local groups is on private enterprise and attracting businesses to their area, whether this is through tourism initiatives, agricultural cooperatives or 'capacity building' programmes. In this respect, alternative conceptions of development, most of which have emerged from the environmental movement over the past three decades, have (with the odd exception) rarely been influential upon community development in Ireland.

\section{'Locals' and 'incomers' in Donegal.}

These observations are reflected in rural Donegal. All villages and towns contain a plethora of community groups, focused on almost all sectors of the population and encompassing numerous and very varied activities. As far as most of them are concerned, however, environmental development is not one of them, since this is generally considered to be of a far lower priority to social and economic development, and, in any case, is something which belongs in the natural ambit of the county council or the European Union. Environmental improvements are rarely pursued as ends in themselves; rather, they occur largely, if they occur at all, as by-products of other development projects.

I begin with a simple observation, namely that people involved in environmental groups in the area of eastern County Donegal where I worked were usually incomers. By environmental groups, I mean those set up for the specific purpose of pursuing environmental projects, along with the local branches of national charities, semistate entities such as An Taisca (Ireland's equivalent of the UK's National Trust) or political parties (notably the Green Party). I have no firm statistical evidence that might support my observation, even if it were possible to generate any. Likewise, I do not know whether this is true of the rest of the county, nor indeed the rest of Ireland. However, research conducted nationally suggests that Donegal is by no means atypical in this respect. A survey of environmental activists conducted by Tovey, for example, found that in most groups, 'outsiders' were very much to the fore: with an over-representation of those from middle-class income categories and many having spent considerable time outside Ireland, something which Tovey neatly characterises as an experience of 'interrupted habitus' (2007: 111). Kelly (2004: 87-8) drew similar conclusions from the results of her focus groups conducted with representatives from various sectors of Irish society. Casey (2000) argues that such dominance by incomers in environmentally focused groups (particularly those with a touristoriented agenda) is inevitable: 'those without ... insight into the [tourist] market will be unable to realise the potential of the environment at their disposal. Moreover, they will show no interest in the resources themselves' (Casey 2000: 266).

I must also preface my material with a word of caution. In any European context, it is obviously difficult, in both practical and academic terms, to make a sharp distinction between 'locals' and 'incomers'. Not only do social groups fail to conform to 
the neat systems of classification which social researchers often like to define them by, but in employing such terms one is necessarily superimposing predetermined categories upon groups of people who may not actually share the researcher's view of who is indigenous to a particular area and who is not. In County Donegal, such a problem is compounded by the localism of population, in the sense that the majority of people tend to regard anyone who was not born and raised in the area where they live as incomers, regardless of where they are from. And sometimes even this is not enough to be regarded as truly indigenous. As an example, a friend of mine in the village in which I was based was regarded as an incomer by many of his neighbours, despite the fact that he had lived there for all of his life. The reason was that his parents were natives of a town thirty miles away, and had moved into the village after they were married. The fact that they chose to build their house on a plot which was originally regarded as 'common land' by the older inhabitants only served to reinforce his and his family's status as 'blow-ins'. ('Blow-in' is the Irish term for incomer.)

In the following discussion, I therefore make no attempt to categorise the population myself; rather, I employ the distinctions made by local people themselves, in order to illustrate the fact that the meaning of the concepts 'local' and 'incomer' vary significantly according to social and geographical context, and also reflect wider social tensions in Donegal.

\section{Environmental groups in Donegal}

The most prominent 'environmental' group in the Irish town or village is usually the Tidy Towns committee. The national Tidy Towns competition began in 1958 under the auspices of Bord Fáilte, the Irish Tourist board, and now attracts over 800 entrants each year. Since 1995, it has been administered by the Department of the Environment, Heritage and Local Government, and has moved away from being an enterprise driven primarily by tourism to become a more broadly based development initiative. According to the Tidy Towns handbook published by the department, the scheme is viewed as an example of the application of Agenda 21 principles established by the 1992 Rio Summit to local levels (Department of Environment, Heritage and Local Government 2002:17). An explicit link is also made between environmental, community, and economic development:

Environmental improvement is a vital part of economic regeneration. Firms will not move into a blighted, uncared for town and tourism will not flourish there.

The town or village that looks good has a better chance to thrive. The very act of environmental improvement creates jobs, raises property values and stimulates the local economy. (Department of Environment, Heritage and Local Government 2002:11)

Environmental improvement is also an essential component of local development programmes coordinated by the ADM Area Partnership groups and LEADER companies 
through their community development programmes. (Department of Environment, Heritage and Local Government 2002:17)

Although the government's efforts are undoubtedly laudable, and exemplify recognition of the importance of the social dimension in environmental initiatives, the contribution of the annual competition to improving Ireland's environment may be more questionable if one holds that sustainability necessarily involves political change. Moreover, in a survey of attitudes towards the competition carried out in 1999, Mercator Market Research suggested that enthusiasm among potential participants is likely to be inversely proportional to the prosperity of the town:

If a town is prosperous there may be more of a predisposition to take part in the competition, buoyed by the ensuing local self-confidence. In areas with economic problems, however, there is less likelihood of people being interested in the competition. Thus, in areas with high unemployment and other social problems there is a sense of dislocation and exclusion from the competition. (Mercator Market Research n.d.: 3-4)

The authors also found that most Tidy Town committees that they examined were run - from the perspective of the majority of the population - by a clique of the 'same old faces'. An observation which could apply to some areas in Donegal.

In Donegal, the term Tidy Towns is actually a misnomer, since it is largely a rural scheme and almost every village has a Tidy Towns committee, even if not all enter the national competition. The important point for the theme of this chapter is that in the case of many of the villages where I did my fieldwork, the more active members of committees were incomers, or, more accurately, were perceived as such by those involved in other community groups. Moreover, the committees also tended, in the main, to be administered by the wealthier residents of an area, often those who had moved into rural Donegal from towns and cities in Ireland and beyond. Their focus was largely on the beautification of an area: litter collection, hedgerow trimming, and whitewashing, in preparation for the anonymous visits of the Tidy Town adjudicators, if the village was participating in the competition. Very few had interests which went beyond aesthetic considerations, into areas such as the relationship between environment and social development, or green politics, for example. Some of the members of community groups with a focus on social and economic issues, which was most of them, were actively disparaging about Tidy Towns committees and their activities. In the words of a chairman of one development group:

The Tidy Towns committee do nothing for the people here. All they're interested in is how nice their own houses look, having nicer window boxes and lawns, and that. And this village isn't going to win anyway, no chance. We'd have to knock everything down and build it again.

If the government's aim in moving the competition away from an emphasis on mere aesthetics reflects a desire to make the committees more representative of local communities, and to encourage a greater degree of involvement from more traditional 
community groups in their activities, then the evidence from Donegal suggests that this is a harder task than it might first appear.

Apart from the Tidy Towns committees, there are few other groups with an explicit environmental agenda in Donegal. And, like the Tidy Towns committees, those that do exist tend to be run by incomers and have a focus on the aesthetics of their local area.

Mary Hegerty is the chairperson of a community development organisation based in a town in the south of the county. It was established in 1996 with the primary aim of acting as an umbrella group for the numerous community groups in the area, along with improving the environment in the town. Mary was born and raised over the border with the UK in Northern Ireland, and lived in England for twentytwo years. She moved to the town in the early 1990s. The various difficulties she has experienced in trying to attract support from the local community and raise funds for the group encapsulates the divide between incomers and indigenes in Donegal.

In 1997, her group attempted to buy a plot of land in the village, in order to build a children's play area. One of the motivations she had for developing the land was to improve the appearance of the village, as the land was overgrown and used by many residents as a dumping ground for rubbish. She approached a local EU-sponsored agency, which told her that she could apply for a grant to buy the land if the landowner was willing to sell it. After extensive enquiries, she eventually discovered that the land was owned by the Church. The group arranged a meeting with the priest, who told them he was not prepared to sell them the land because the price would be too cheap compared to selling it to a commercial buyer and that the group should not be spending money on such projects anyway which, in his view, were not beneficial to the whole community. In Mary's view, however, the priest's real reasons had more to do with the fact that she was not a practising Catholic and had never attended any of his services. In her words: 'In this town, power is in the hands of three people: the priest, the councillor, and the teacher. And you have to be in with all three to get anything done. But they're suspicious of me because they see me as an outsider, a blow-in.'

Another example comes from a town in the east of the county, and one particular public housing estate on its outskirts called Kilcarroll. The estate has had a long history. Although the first houses were built in the 1960s, the final phase was only completed in 1994. In 1997 it had 127 homes, with an estimated population of about 500. A residents association was established for the estate in 1995, principally in order to lobby the county council to make environmental improvements in the area, but a specific event also gave impetus to the group's activities.

Shortly after its formation, the group learned that a motion had been passed in the county council to sell a piece of land adjacent to the estate which had been earmarked as a children's play area in the original plans. A particular councillor for the town was behind the decision, and there were rumours at the time that he was acting as a broker between the council and the potential buyers of the land, and may 
have profited personally from the sale. A number of individual residents organised a petition, and collected 180 signatures from people on the estate. However, the council campaigned hard against the association, with a number of councillors alleging in the chamber that many of the names on the petition had been falsified by the Residents Association committee, which had, in any case, not been properly elected at a full public meeting. The Residents Association responded by taking the council to a planning appeal hearing, which resulted in the council overturning its decision and promising to build a children's play area on the land as originally planned.

This account was told to me by the chairman of the Residents Association, and the way it was couched says much about the importance of the local/incomer dichotomy in Donegal. First of all, the Residents Association argues that the environment in and around the estate has been neglected by the council for many years because no councillors live on it. In the chairman's words, 'They're not locals, they all live in the private houses at the other end of town, and never come down this way.' The council, for its part, argued that the Residents Association did not represent the views of the majority of people, and that the petition was made up of the signatories of 'strangers' who did not live there. Finally, although the Residents Association estimated that 80 per cent of the estate's residents were approving of its activities, they admitted that 20 per cent were opposed to everything they do. To quote the chairman again: 'The diehards we call them. They think it's all a waste of time. These are the people who moved into the first houses in the 1960s, and they have been there for such a long time. They think it's their estate and see us as the blow-ins.'

Some groups have moved beyond aesthetics in an attempt to pursue a more authentically 'green' agenda. One such group is the Inverkenny Development Association, an environmental group based in the north of the county. The group is concerned primarily with promoting the natural beauty of the area, by publishing brochures, running marketing campaigns and creating a network of walking trails, but is also hoping to move into the promotion of sustainable livelihoods among local residents. The chairman of the group, Gerry O'Leary, was born and raised in Northern Ireland, but lived in Canada for twenty-five years before returning to Ireland in the early 1990s. Around his large, eighteenth-century farmhouse he owns seventeen acres of land, which he uses for growing food for himself and his family, cutting hay and turf and exercising his four horses. Gerry tends to avoid supermarket shopping if he can, encouraging his family and friends to pursue a lifestyle based on an environmentally sustainable agenda, something which he argues is largely shared by members of his own group.

The townland he lives in has become a haven for immigrants, with a significant proportion of the population composed of people recently arrived in Donegal. They include a retired American army colonel, a former leader of Cork County Council, a German computer technician, and a white witch who used to live in Iran. ${ }^{4}$ Many of them are involved in the development group. Gerry's attitude to development in the area is very much that of the outsider. He argues that most of the local 'native' 
population, whom he always refers to in the third person, do not really care about development, which he considers to be principally about the environment.

You could plant an entire hillside with trees and no one in [the local village] would bat an eyelid. They don't realise that the acid that comes off them will pollute all the brooks around here. There's a plantation down the road owned by some guy from Leitrim. He's never even visited the place, just bought it as an investment. When the trees are harvested, they'll ship all the timber over to mills in the north and destroy all the roads on the way in the process. I wouldn't mind if there were mills round here that were creating jobs for local people, but there isn't. The guy'll get $£ 50$ a tonne for the wood, which will bring him a fortune. People round here should be campaigning against this sort of thing, but they couldn't give a damn.

The development association works largely autonomously and has few links with other community groups in the area (of which there are several). Gerry argues that the ecotourism approach which his group is promoting will only be beneficial to the local population in the long term, particularly by creating job opportunities, but has become increasingly frustrated by what he views as the lack of interest, and sometimes active hostility, shown by his indigenous neighbours towards his activities.

\section{Local politicians}

Some of the examples cited above hint at the often acrimonious relationship between the county council and local community groups in Donegal. Councillors view themselves as the authentic representatives of the population and are generally suspicious of most development groups in the county, which they see as undermining local democracy (Collinson 2005). And the fact that many environmental groups are led by incomers to the area only serves to heighten the antipathy they hold towards them, particularly as incomers are often blamed for having a distorting effect on the economy of the county by pushing up the price of housing (at least until the economic crash of 2007-08). The vast majority of councillors are also farmers or businessmen, something which further colours their perspective on environmental issues. Finally, they are largely male, ${ }^{5}$ in contrast to the majority of development groups which tend to be dominated by females. There is thus an additional genderbased dimension to the divide between councillors and community groups, with economic and community (including, indeed especially, environmental) development being associated respectively with male and female spheres of activity.

Councillors obviously represent the public face of the council, and inevitably get the blame if their constituents feel that their area is being neglected. There is, however, a clear division between councillors and the county council executive, particularly in relation to environmental matters. Although the executive has several environmental programmes and initiatives in place (see, for example, Donegal County Council 2006), for most councillors improving the environment usually takes very much a secondary role to economic considerations. Councillors have 
few real powers in Ireland, and their main roles are focused on a fairly narrow set of concerns which surround securing benefits for their constituents, such as planning approvals, grants, employment with the council, social security and medical cards, and school placements.

Environmental matters, when they are raised in the council chamber, are largely related to issues such as improvements to the water, drainage, and sewage infrastructure of the county. Councillors sometimes raise motions relating to the aesthetic appearance of particular areas, but it is notable that these are rarely targeted at the effects of economic development:

Cleaning up refuse and scrap left by travelling people ... Clr ... asked that the council considered closing the road at Ray, Manorcunningham, where a particularly bad problem existed with travelling people. ${ }^{6}$

That this council take immediate action to resolve the problem for the people of Magherecar, Bundoran, caused by the period parking in that area of large groups of mobile travelling families and the subsequent rubbish accumulation that occurs as a result of their stay. ${ }^{7,8}$

Despite their relative impotence, councillors have traditionally had one particular instrument by which they can exert power over the county council executive, which is something known as the Section Four motion. In theory, this is a measure by which councillors can force the executive to carry out their wishes, as long as at least three quarters of the elected members support a proposal. In the late 1990s the instrument was invoked on a regular basis in the council chamber in Donegal. It was usually applied in relation to housing, instructing the council to grant planning permission for new houses, extensions, etc., and its use was particularly prevalent at election time.

A number of high profile legal rulings in favour of county managers in the early 2000s led to the demise of the use of the Section Four motion in most local authorities, including Donegal (Sheehy 2003: 134-5). But the motion partly explains the often haphazard way in which housing development was pursued in Ireland until recently, and the apparent lack of planning controls there were upon it. In the words of one councillor: 'In the past, if you were in with the right people on the council, you could build a house in the middle of the street if you wanted to.'

Despite the demise of the Section Four motion, tensions still arise between the executive and the council in relation to planning applications, as in this exchange regarding a proposed housing development in the east of the County:

[Senior Planner's report] It is considered that the proposed development is located on visually sensitive lands on the lake shore where development would both intrude significantly on and materially alter the view to be had from the adjoining National Secondary road. Accordingly, the proposed development contravenes the aforementioned provision of the County Development Plan, 2000 (as varied) and would, therefore, be contrary to the proper planning and sustainable development of the area. 
Clr ... advised that the development would in no way impede the view of [the lake]. Vision lines, he stated, were adequate and the applicants had confirmed that every effort would be made to ensure that overgrowth etc. was curtailed. A number of members highlighted the fact that the applicant was a member of the indigenous community and building on family land. ${ }^{9}$

This exchange also serves to highlight views on the attitude of councillors to indigenes versus 'blow-ins'. In this respect, as in relation to attitudes to the environment, there is likely to be a strong correspondence between the views of councillors and those of the general population.

\section{Conclusion}

The evidence presented here suggests that there is a complex range of attitudes to the environment on the part of those involved in development in Donegal. Assuming that national surveys are representative of the population of the county, economic considerations take precedence over the environment issues for most people, something which is only likely to have deepened during the recent recession. Local councillors tend to reflect this view. Community groups also by and large focus on socio-economic issues, with environmental development only weakly articulated in the county and concentrating largely on aesthetics (e.g. in the case of the Tidy Towns committees). Finally, there are a small number of groups which are attempting to pursue a more authentically 'green' agenda, exemplified by the Inverkenny Development Association. The proportion of 'incomers' (even though they may not see themselves as such) compared with 'indigenous' participants tends to increase with a greater emphasis on environmental issues. Of course, not all incomers are only interested in the environment, and many are very active in other types of community groups as well. But the difficulties some incomers have in integrating fully with the local population, and being accepted by them, is an experience which is shared across groups. ${ }^{10}$

So, what does all this tell us? That the Irish don't care about the environment? No, certainly not. The concerns of the Kilcarroll residents regarding the appearance of their estate are just as strongly held as those of the chairman of the Inverkenny Development Association about the natural environment in his area. But there is certainly a tension between those who see the environment in purely aesthetic terms and those who have a more conservationist approach (see Tovey et al. 2007: 533). It is also clear that environmental attitudes are strongly related to social background, with incomers (who are often wealthier than 'indigenes') much more likely to be involved in environmental activism. It follows from this that the environment means very different things to different people in Ireland, and there are different discourses pertaining to it. This provides a partial explanation for the observation that in Donegal, and probably elsewhere in Ireland, environmental development tends to fall between several stools, with the result that it has been historically neglected in the overall development agenda. 
Mary Kelly (2007) identifies a number of types of discourses relating to the environment in Ireland, drawing from her research on environmental attitudes among a number of different sectors of the population. She argues that there are six principal discourses, which she characterises as moral, radical, political, romantic, scientific, and regulatory. While none of the group discussed above fits neatly into these categories, it could be argued that a number of environment development groups in Donegal are associated with a moral discourse frame: an ethical desire to preserve the environment for the benefit of the community and future generations (Kelly 2007: 16-17). Some, most notably the Inverkenny Development Association, are probably also driven by romantic notions of Ireland as well, and their 'emotional response' (Kelly 2007: 88) to the landscape, and perhaps by a radical political agenda too. But most development groups, and certainly the county council, fall into the regulatory discourse frame, characterised by a focus on the pursuit of economic growth in conjunction with environmental protection. Kelly notes that this was the dominant discourse among all the groups she studied, with most participants acknowledging the inherent tensions embedded in this relationship (Kelly 2007: 37).

As I hope to have shown here, there are also specific social tensions which underlie these different discourses. Incomers to rural areas in Donegal have often moved in specifically because of the beauty of the natural environment. In the main, they are more affluent and better-educated than the native population, and have therefore more inclination to become involved in development projects that have a specific environmental focus. They are more likely to have a 'green' political outlook, growing their own food, recycling rubbish, using cycles instead of cars, etc. For people who have been born and bred in Donegal on the other hand, participation in development activities tends to be motivated by their own everyday concerns: employment, training and education, agricultural development, family welfare, social inclusion, and so on. Only in urban public housing estates like Kilcarroll do community groups tend to have both a social and an environmental agenda, but here the environment is conceived simply in terms of physical appearance, with nothing of the extra accoutrements such as green politics which is the case among some of the incomers in rural Donegal. And in rural areas, groups operate separately, just as incomers and locals are largely separated into their respective social - and often geographical - ambits, which further serves to compound the piecemeal nature of the development process. As Tovey points out:

The environmental movement in Ireland is composed of groups of 'competent actors', acting within an existing social and cultural context, to whom their own engagement appears a reasonable course of action given their personal formation as individuals, their frameworks of meaning and their social situations. (Tovey 2007: 184)

The economic crisis which has gripped Ireland since 2008 has focused attention on the deleterious effects of the boom years of the preceding decade or so. Some 
in the environmental movement in Ireland may argue that the economic crash is a blessing in disguise, putting a halt to what they see as Ireland's unsustainable overdevelopment. However, others may take the view a reversion to the bad old days of mass unemployment, social exclusion, and emigration is a heavy price to pay for environmental protection. The tensions between sustainability and economic reality continue to frame the environmental debate in Ireland and serve to shape competing discourses of development, the latter firmly rooted in, informed by and impacting upon social relationships between different groups of local actors.

\section{Notes}

1 The Green Party now (2014) has no members in the Irish parliament (Dáil Éireann) for the first time since 1989.

2 All personal and place names have been changed to protect the anonymity of informants.

3 NIMBY means 'not in my backyard'.

4 It is worth noting that the environmental activists interviewed by Tovey for her 2007 study display a similar eclecticism.

5 Of the twenty-nine members of the council elected in the 2009 election, only three were female.

6 Donegal County Council Minutes of Meetings, 24 February 1992.

7 Donegal County Council Minutes of Meetings, 25 January 1993.

8 An increase in the number of permanent sites for travelling people during the past ten years and the instigation of the Donegal Local Traveller Accommodation Consultative Committee in 2002, which includes three representatives from the community, appear to have curtailed the raising of the type of motions cited above.

9 Donegal County Council minutes of meetings, 25 January 2005.

10 It is notable that this observation stands in contrast to the findings of Ruth Casey, in her study of the pseudonymous village of Ballygannive in western Ireland, where incomers are perceived as having stimulated a culture of environmental activism in the area and are lauded for this (Casey 2000: 264-7).

\section{References}

Barry, John and Peter Doran 2009 'Environmental Movements in Ireland: North and South', in J. McDonagh, T. Varley, and S. Shortall (eds) A Living Countryside? The Politics of Sustainable Development in Rural Ireland (Farnham: Ashgate), 321-40.

Casey, Ruth 2000 'Virtual locality', in E. Slater and M. Peillon (eds) Memories of the Present. A Sociological Chronology of Ireland 1997-8 (Dublin: Institute of Public Administration), 259-71.

Collinson, Paul 1999 Development, Local Politics and the 'New Europe' in County Donegal Unpublished PhD Thesis (Oxford Brookes University).

2005 'Development, democracy and the New Europe in the Irish Borderlands', in T. M. Wilson and H. Donnan (eds) Culture and Power at the Edges of the State (Munster: Lit Verlag), 289-320. 
Coyle, Carmel 1994 'Administrative capacity and the implementation of EU environmental policy in Ireland', in S. Baker, K. Milton, and S. Yearly (eds) Protecting the Periphery. Environmental Policy in Peripheral Regions of the European Union (Newbury Park: Frank Cass), 62-79.

Curtin, Chris 1997 'Community development in Ireland: an historical overview', Paper presented at IRDL Conference on Cross-Border Cooperation (Moville, 10 May).

Deegan, J. and D. A. Dineen 1997 Tourism Policy and Performance: The Irish Experience (London: International Thomson Business Press).

Department for Environment, Heritage and Local Government 2002 Tidy Towns Handbook (Dublin: Department for Environment, Heritage and Local Government).

Dillon, Sara 1996 'Vulnerable landscapes and the inadequacies of the Irish planning acts', Dublin University Law Journal, 102, 102-25.

DKMEconomic Consultants 2009 Review of the Construction Industry 2008 and Outlook20092011 (Dublin: Department of the Environment, Heritage and Local Government).

Donegal County Council 2006 County Development Plan 2006-2012 (Lifford: Donegal County Council). Published at www.donegalcoco.ie/services/planningeconomicdevelopment/Central+Planning+Unit/countydevplan.htm. Accessed 12 July 2011.

Flynn, Brendan 2009 'Environmental lessons for rural Ireland from the European Union: how great expectations in Brussels get dashed in Bangor and Belmullet', in J. McDonagh, T. Varley, and S. Shortall (eds) A Living Countryside? The Politics of Sustainable Development in Rural Ireland (Farnham: Ashgate), 53-68.

Irish Examiner 2010 'Unfinished business' (6 April). Published at www.examiner.ie/ireland. Accessed 26 April 2010.

Kelly, Mary 2004 Environmental Attitudes and Behaviours: Ireland in Comparative European Perspective: Third Report of National Survey Data (Dublin: Social Sciences Research Centre, UCD).

2007 Environmental Debates and the Public in Ireland (Dublin: Institute of Public Administration).

Leonard, Liam 2007 The Environmental Movement in Ireland (Galway: Social Sciences Research Centre, National University of Ireland / Springer).

McDonagh, John 2007 'Rural development in Ireland - retrospect and prospect', in B. Bartley and R. Kitchin (eds) Understanding Contemporary Ireland (Pluto Press), 88-99.

McDonagh, John, Tony Varley, and Sally Shortall (eds) 2009 A Living Countryside? The Politics of Sustainable Development in Rural Ireland (Farnham: Ashgate).

Meldon, J. 1992 Structural Funds and the Environment: Problems and Prospects (Dublin: An Taisce).

Mercator Market Research n.d. Attitudes to Tidy Towns. Published at www.environ.ie/ en/Environment/TidyTowns/PublicationsDocuments/FileDownLoad,2390,en.doc. Accessed 3 April 2010.

Motherway, Brian, Mary Kelly, Pauline Faughnan, and Hilary Tovey 2003 Trends in Irish Environmental Attitudes between 1993 and 2002. First Report of National Survey Data (Dublin: Environmental Protection Agency).

Peillon, Michel 2002 'Culture and the state in Ireland's new economy', in P. Kearby, L. Gibbons, and M. Cronin (eds) Reinventing Ireland: Culture, Society and the Global Economy (London: Pluto), 38-53.

Sheehy, E. 2003 'City and county management', in M. Callahan and J. F. Keogan (eds) Local Government in Ireland: Inside Out (Dublin: Institute of Public Administration), 123-42. 
Skillington, Tracey 1997 'Politics and the struggle to define: a discourse analysis of the framing strategies of competing actors in a 'new' participatory forum', British Journal of Sociology, 48:3, 493-513.

- 1998 'The city as text: constructing Dublin's identity through discourse on transportation and urban regeneration in the press', British Journal of Sociology, 49:3, 456-73.

Sklair, Leslie 2009 'The transnational capitalist class and the politics of capitalist globalization', in S. Dasgupta and J. N. Pieterse (eds) Politics of Globalization (New Delhi: SAGE), 82-97.

Tovey, Hilary 2007 Environmentalism in Ireland. Movement and Activists (Dublin: Institute of Public Administration).

Tovey, Hilary, Perry Share, and Mary P. Corcoran, 2007 A Sociology of Ireland (Dublin: Gill and Macmillan, 3rd edn).

Varley, Tony 2009 'Populism and the politics of community survival in rural Ireland', in J. McDonagh, T. Varley, and S. Shortall (eds) A Living Countryside? The Politics of Sustainable Development in Rural Ireland (Farnham: Ashgate), 341-60.

Wickham, James and Maria Lohan 2000 'Dublin's car system', in E. Slater and M. Peillon (eds) Memories of the Present. A Sociological Chronology of Ireland 1997-8 (Dublin: Institute of Public Administration),77-9.

Yearley, Stephen 1995 'The social shaping of the environmental movement', in P. Clancy, S. Drudy, K. Lynch, and L. O’Dowd (eds) Irish Society. Sociological Perspectives (Dublin: Institute of Public Administration), 652-74. 